\section{OAK RIDGE NATIONAL LABORATORY \\ Operated-by}

UNION CARBIDE NUCLEAR COMPANY

Division of Union Carbide Corporation

\section{UCC}

Post Office Box X

Oak Ridge, Tennessee
ENERGY

DATE:

December 26, 1958
EXTERNAL DISTRIBUTION AUTHORIZED

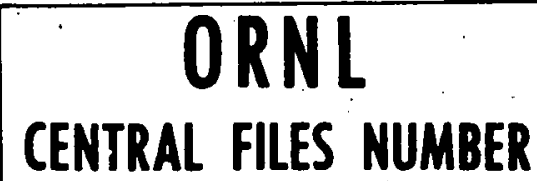

$58-12-154$

COPY NO.

SUBJECT: Inspection and Maintenance Experience with HRE-2 (Presented at the Nuclear Eagineering and Science Conference in Cleveland, Ohio,

TO: in April 1959)

FROM: J. S. Culver, D. M. Shepherd and C. W. Collins

\title{
ABSTRACT
}

Experience in replacement of highly radioactive components of Homogeneous Reactor Experiment No. 2 is discussed, wi.th particular emphasis on containment of air-borne contamination and control of personel exposure. The design and operation of tools and viewing devices developed to observe the hole in the HRE-2 core tank are described.

\section{NOTICE}

This document contains information of a preliminary noture and was prepared primarily for internr:! use of the Oak Ridge National Laboratory. it is subject to revision or correction and therefore does not represent a final report. The information is not to be abstracted, reprinted or otherwise given public dissemination without the approval of the ORNL patent branch, Legal and Information Contral Department. 


\section{DISCLAIMER}

This report was prepared as an account of work sponsored by an agency of the United States Government. Neither the United States Government nor any agency Thereof, nor any of their employees, makes any warranty, express or implied, or assumes any legal liability or responsibility for the accuracy, completeness, or usefulness of any information, apparatus, product, or process disclosed, or represents that its use would not infringe privately owned rights. Reference herein to any specific commercial product, process, or service by trade name, trademark, manufacturer, or otherwise does not necessarily constitute or imply its endorsement, recommendation, or favoring by the United States Government or any agency thereof. The views and opinions of authors expressed herein do not necessarily state or reflect those of the United States Government or any agency thereof. 


\section{DISCLAIMER}

Portions of this document may be illegible in electronic image products. Images are produced from the best available original document. 
This report was prepared os an occount of Government sponsored work. Neither the United States, nor the Commission, nor any person acting on behalf of the Commission:

A. Makes any warranty or representation, expressed or implied, with respect to the accuracy, completeness, or usefulness of the information contained in this report, or that the use of ony information, apporatus, method, or process disclosed in this report may not infringe privately owned rights; or

B. Assumes ony liabilities with respect to the use of, or for damages resulting from the use of any information, apparatus, method, or process disclosed in this report.

As used in the obove, "person acting on behalf of the Commission" includes ony employee or contractor of the Commission, or employee of such contractor, to the extent that such employee or contractor of the Commission, or employee of such contractor prepares, disseminates, or provides access to, any Infurmation pursuant to his employment or contract with the Commission, or his employment with such contractor. 
INTRODUCTION

Maintenance of equipment in the circulation systems of the Homogeneous Reactor Experiment No. 2 (HRE-2) presents difficulties because fission product activities are not confined to the reactor core and intense radioactivity emanates from the surfaces of the equipment. Despite the difficulties, however, this problem must be resolved in a practical manner if circulating-fuel reactors are to be economical power producers.

The development of malntenance practices for HRE-2 was described in a report to the Fourth Nuclear Congress( 1 ). In the year 1958, experience was gained in the application of these practices to the replacement of reactor components during shutdown periods after power operation. Total down time for the year attributable to maintenance was $1200 \mathrm{hr}$, including $600 \mathrm{hr}$ for re. placement of the entire reactor power wiring system. Power operating time during this period was $2700 \mathrm{hr}$; a total of $3200 \mathrm{hr}$ was spent conducting chemical experiments and inspections relating to the fuel behavior. The length of time between reactor shutdown and the start of direct maintenance varied from 36 to $60 \mathrm{hr}$, depending on whether dry or wet operations were done. Three of the four shutdowns were scheduled in accordance with the experimental program of the reactor; the fourth was after discovery of a leak in the reactor core tank. Not one mechanical fallure was experienced in 1958 which made the reactor plant inoperable or which required immediate maintenance.

The first sections of this report describe some of the typical maintenance experiences during the shutdown periods. The tools and techniques used in normal component replacement were . expanded to permit their use in making minor system modifications. The metbods used in personnel protection and in control of contamination have proved successfiul.

Following the appearance of an opening the wall of the Zircaloy-2 core vessel, a sbort-range program was conducted to design, construct, test and operate equipment to observe the hole in the core. A similar program was carried out in order to retrieve a number of corrosion specimens, exposed in the center of the reactor core, which bad become detacbed from tbeir holder during reactor operation. A description of the inspection and. retrieval programs comprises approximately the last half of this rêport.

\section{GENERAL MAINTENANCE EXPERIENCE}

\section{Control of Contamination}

To control the spread of contamination from radioactive components and tools used in various operations, the roof plugs over the reactor cell were covered with plastic film. In areas of heavy traffic, plywood was used to protect the plastic from punctures. Heavy blotter paper was then spread over areas where 
contaminated items would be handled, stored, or transported.

A traffic pattern was established (see Fig. 1) to prevent the inadvertent spread of contamination. All personnel entered and left the area over the reactor cell via the temporary change room. All imcoming clean tools and equipment were passed over the barrier from the south. All contaminated equipment or waste left the building in hot trucks loaded directly at the west end or from the hot storage pool at the east end.

This storage pool provides a safe place for radioactive components or tools which must be used again prior to decontamination. A 4-ft-diameter tank within the pool provides a means of controlling the volume of waste water which must be disposed of when highly contaminated components are placed in it for observation, sectioning for corrosion examination, or other operations.

Downdraft ventilation was provided in the immediate working area by means of a fan drawing air through the cell opening, and exhausting it up a stack. Air change over the top of the reactor cell is provided by roof ventilators. The roof fans were shut down during removal of highly contaminated items from the cell, to prevent air-borne contamination from spreading. In addition an air purge was provided for hollow tools inserted in the core to prevent a chimney effect from carryling air-borne contamination up to the operator.

Tools, lights, periscopes, and other devices used on or in the pressure vessel were enclosed in plastic-film bags as they were withdrawn (see Fig. 2). The top of the bag was taped to the tool handle. A fiber drum, with heads removed, held the bag open while the tool was withdrawn by the overhead crane. A drawstring closed the bottom of the bag when the tool was fully withdrawn; hand lines provided a means of guiding when required.

All personnel were provided with protective clothing consisting of shoes, socks, coveralls, caps, shoe covers, and rubber gloves before entering the area over the reactor cell. Shoe covers and gloves were changed frequently as they became contaminated. Gas masks were used whenever highly contaminated items were withdrawn from the cell, until there was assurance that no air-borne activity was present. Protective clothing was removed in the change house before personnel entered the clean area.

Monitoring of Personnel Exposure

Constant air monitors were used to detect air-borne contamination. Perlodic checks of film badges and daily checks of pencil dosimeters provided a record of personnel exposure. In addition, self-reading dosimeters were used for a constant indication of exposure during operations where dally tolerances might be exceeded. 
A health physics surveyor monitored all bot operations and checked all personnel out through the change room. Blotter paper was changed as it became contaminated, and clean areas were frequently smeared to detect any contamination spread. Throughout all operations, a successful effort was made to limit personnel exposure to an Integrated dose of $300 \mathrm{mr}$, which is the weekly tolerance.

\section{Shielding of Personnel}

Adequate personnel shielding must reduce radiations to tolerable biological values while simultaneously providing access to the equipment. In performing dry-maintenance operations; a hollow lead shield with an eccentric top plug was used to place a variety of tools and other devices over the desired component. Visibility was provided by means of a light and alolosed-circuit television camera lowered through the top plug, or by a glass shielding window installed in the television-camera opening.

Where larger cell openings were required, water shlelding was provided by flooding the cell to the desired level. A lead-covered working platform was used. when it was desirable to replace a component with the cell only partially flooded.

All work, both underwater and dry, was done directly with tools having extension handles up to 25 ft long. An overhead crane spanning the reactor cell area was used extensively in handling these tools and other equipment. During the transfer of hot components from the reactor cell to the storage pool, the overhead. crane was operated remotely. Cell roof plugs were stacked up to provide shadow shielding for the crane operator, health physics. surveyor, and supervisor.

\section{Typical Underwater Maintenance Operation}

A typical underwater maintenance operation was the replacement of an air-operated high-pressure valve. with the work area prepared as described earlier, the cell was flooded to an elevation approximately 18 in. below the bottom of the lower roof plugs. This elevation was chosen to permit dry inspection. to proceed concurrently in the reactor vessel. Upper shield plugs were removed, and the metal cell-sealing membrane was cut open. Lower roof plugs were then removed, exposing the valve.

The lead-shielded work platform was placed over the area, covering all but the required work space. The radlation background was $400 \mathrm{mr} / \mathrm{hr}$ at 3 ft above floor level over the opening, but less than $10 \mathrm{mr} / \mathrm{hr}$ over the work platform. If the cell had been completely flooded, the radiation level would have been much lower. Underwater lights and Plexiglas-bottom viewing boxes in the water provided visibility.

Process lines to the valve were frozen off to prevent shield-water inleakage. Air and leak-detector lines were disconnected with special tools devised for the purpose. Horizontal flanges were unbolted. with extension wrenches. When the 
valve was free, the lead platform was removed. A lifting hook suspended from the overhead crane was eagaged in the valve lifting bail.

Personnel except those required for the hot transfer to the storage pool were evacuated from the buflding. With the crane being operated remotely, the valve was raised clear of the cell and transferred to the storage pool. The valve was found to read $10 \mathrm{r} / \mathrm{hr}$ at $I \mathrm{ft}$ when raised above the cell shielding water.

Installation of the new valve was essentidily a reversal of this procedure. The total time required for removal and replacement, exclusive of opening and closing the cell, was 14 crew hours. There was no significant spread of contamination from tools or the valve.

\section{Typical Dry Maintenance Operation}

:The removal of the fuel corrosion-specimen assembly from the core of the reactor is typical of the dry-maintenance operations performed with the use of the eccentricoplug lead shield. After. preparation of the work area, it is necessary to remove only one upper shielding plug. A flanged cover is provided in the reactor sealing membrane, and a round concrete plug is remotely removed to permit access to the cell.

Tools for removing bolts from the reactor access flange were assembled in the eccentric-plug lead shield, which was then placed over the open bole with the crane. A light and television camera were lowered to view the operations. By use of a wrench with an extension handle the eight flange bolts were loosened. The shielding was quite effective, the background around the shield being only $10 \mathrm{mr} / \mathrm{hr}$ although the beam above the open hole was $10 \mathrm{r} / \mathrm{hr}$ $3 \mathrm{ft}$ above the top of the shield.

The corrosion-specimen assembly and flange were drawn up into a transport tube $9 \mathrm{ft}$ long and 12 in. in diaméter. At this point the radiation field around the lead. shield rose to about $1 \mathrm{r} / \mathrm{hr}$ at 6 in.

The building was evacuated except for the crane operator, health physics surveyor, and supervisor, tho took stations behind. the concrete shadow shield. Mirrors provided visibility as the transport tube was raised above the lead shield and the bottom was remotely sealed with adhesive paper. The tube was then moved. to the storage pool, where a television camera monitored the lowering of the tube into the 4-ft-diameter tank.

The transport tube containing the specimen assembly read 204 $\mathrm{r} / \mathrm{hr}$ at $3 \mathrm{ft}$ when clear of the lead shield. At this time, the background some 30 to $40 \mathrm{ft}$ from the specimen assembly rose to $9 \mathrm{r} / \mathrm{hr}$ above the shadow shleld and $1 \mathrm{r} / \mathrm{hr}$ was read behind the shadow shield. The latter background could have been reduced readily with additional shielding. A field of $20 \mathrm{r} / \mathrm{hr}$ was measured over the top of the water level in the storage tank, with the specimen assembly just below the surface. After the assembly 
had been lowered further into the water, the fleld was reduced to $700 \mathrm{mr} / \mathrm{hr}$ at $6 \mathrm{in}$. above the water surface.

The removal operations required 23 crew. hours of work. The maximum personnel exposure recelved was $110 \mathrm{mr}$. Some contamination was found on the path followed in transporting the specimen assembly to the pool, but it was confined to the blotter paper and was thus easily removed.

\section{Other General Maintenance Operatiońs.}

Other maintenance operations of sigalficance which have been performed are shown in Table I. Jobs listed as wet were performed with the cell flooded or partially flooded; those listed as dry were performed by use of the eccentric-plug lead shield.

The basic crew consisted of a rigger, crane operator, millwright, pipefitter, laborer, health physics surveyor, and supervisor, the crew complement being varied somewhat depending on the nature of the work to be performed. The crew bours tabulated reflect only those hours actually on the job, not those spent in preparation or cleaning up." It should be pointed out that the total reactor down time is greater than that tabulated for the specific maintenance operation. The average operating time lost to permit a dry maintenance operation was $50 \mathrm{hr}$ plus the time needed for the maintenance work. The corresponding average down time for a wet operation was $80 \mathrm{br}$.

The maximum activity levels are those to which personnel were exposed in working, however briefly, and do not sigaify that personnel were working continuously in this radiation environment. Maximum personnel exposures are the bighest received by any one crew member during an entire job.

OBSERVATION OF THE CORE DEFECT AND CORROSION-SPECIMEN RECOVERY

Immediately after the leak in the core tank was confirmed, a program was initiated to determine the size, location, and, if possible, the nature of the defect. The elevation of the leak was established by pumping up $\mathrm{D}_{2} \mathrm{O}$ coadeasate until it overflowed from the blanket into the core as evidenced by an increase in dump-tank welght. Further refinements were made utilizing bubblers to establish the level at the spillover polat. The approximate elevation thus established was at the latersection of the two cones in the lower half of the core vessel. Since this region is below the top diffuser screen, it could not be observed from inside the core vessel at the time.

Figure 3 illustrates the relative position of the core and bianket vessels and their access flanges with respect to the shielding used in dry-maintenance operations. The typical working distance is about $18 \mathrm{ft}$. The core access flange is only 2 in. in inside diameter; the north side of the blanket vessel has a $31 / 2-i n .-I . D$. access port. 
Measurement of radiation level in the core was attempted, and the instrument went off scale at $60,000 \mathrm{r} / \mathrm{hr}$ as it entered the vessel outlet pipe.

All tools to be described in this section were designed for a particular job and were considered expendable. Although in some instances 1t was posisible to store the tool in a dry well in the storage basin for re-use, most of the tools and viewing devices read 4-6 r/hr on removal and were bagged and hauled to the burlal ground in a hot truck immediately after use.

Program to View Core Defect

A 20 -ft periscope $13 / 4-10$. ix diameter was constructed using conventional optical glass lenses and a Stellite mirror set at $45 \mathrm{deg}$ to allow horizontal viewing in the blanket vessel. With this device the outside of the core vessel. was observed and photo. graphed on the north side. Light was supplied by pbotoflood lamps protected by screen enclosures. To observe the soutb side, an. additional device was constructed with an arm which could be erected in the annular space between the core and blanket vessel. A light source and mirror which could be rotated independently by cables runaing up through the shield plug were attached to this arm. With this combination, it was possible to observe the image in the mirror with the periscope and thus see part of the south surface of the core vessel. All areas which could be observed were studied; however, the defect was either not seen or not recognized.

During the ensuing period while the reactor was belag operated as a single-region machine, a concerted effort was made to. build and test better equipment to view the core defect. The initial step was the construction of a full-osize malatenance mockup which simulated the geometry of the reactor core and blanket vessels and could be approached from above at the appropriate elevation.

The first mockup application was evaluation of the equipment used in the initial viewing attempt to determine its adequacy. The quality of the image obtained with the optical periscope and mirror was found to be good, but the field covered by the rotating mirror omitted about 90 deg of the vessel at the ele-" vation of the defect. Furthermore, the lightiag was found to be marginal when the surface viewed was dull.

During the period of reactor operation following the unsuccessful viewing attempt, a revised design of the folding-arm device was constructed as shown in Fig. 4. The new device contained a long air-tight box with a non-browning fused pure silica window, which enclosed the periscope. The folding arm, to which were attached two 220 watt projection lamps and a rotating mirror, was mounted below the box. The new viewing device was tested rigorously in the mockup to insure its proper operation in the reactor. Figure 5. illustrates the lower end of the device erected in the mockup. 
In order to plapoint the azimuth and elevation of the leak, oxygen was admitted through the reactor blanket addition system and permitted to:bubble through some heavy water placed in the core to just above the top diffuser screen. Bubbles rose in bursts at 30-sec intervals, rising through the same screen opening repeatedly. The azimuth was found to be about $30 \mathrm{deg}$ west of south in the area not visible during earlier viewing. Projecting the observed radius confirmed the elevation of the defect to be at the intersection of the cones.

The bubbles were observed through the core flange opening with a tilting-mirror periscope contalniag no leases. The mirrors were Alzac coated glass, and a surveyors transit telescope was used for magnification. Light was supplied by two 300 watt projection lamps, encased in screen and operated at $50 \%$ of rated power. During this operation several fuel corrosion specimens, which had been detached duriag reactor operation, were observed on the top screen.

With the azimuth thus fixed, the folding-arm device was inserted through the blanket access flange and erected on the west side of the core. A minor adjustment of the mirror brought the hole into view.

Browning of the periscope lenses reduced the brilliance of the image rapidly, but sufficieat viewiag time was available to photograph the hole and allow several people to observe it. A second similar periscope was rapidly browned up by further viewing. These were then replaced by a tiltiog mirror periscope of the type used previously in the core which supplied an image nearly as clear as that of the new glass scope. This equipment served satisfactorily for three days, allowiag study of the nature of the hole, and providing the photographs shown in Figure 6 . Owing to the limited field of view in the $2 \times 4 \times 10$. mirror, it was necessary to take three pictures to bring out the detail of the hole and the tail that extends below it. The silhouette of the core vessel can be seen at the left side of the image in the mirror.

\section{Cutting of Screen Samples from the Core Diffuser}

Origiaal plans called for 1-10.-dfameter samples to be cut from the top diffuser screen adjacent to the core wall for metallurgical study. A tool to accomplish this was desigmed, built, and successfully tested; however, following viewiag of the core defect from the outside it was decided to construct anotber tool to cut 2-in.-diameter discs out of the center of the top six screens. This would accomplish the following objectives: (i) give an access port for the tilt-mirror periscope so that the hole in the core wall could be viewed and photographed from the inside, (2) provide a series of Zircaloy-2 samples which bad experienced a range of neutron fluxes, (3) provide a well in which a receptacle could be placed to ald in retrieviag the corrosion specimens which had fallen onto the top screen. 
Tests run in the shop showed that Zircaloy-2 could be successfully cut with water being used as a lubricant and coolant if the cutter speed did not exceed $60 \mathrm{ft} / \mathrm{min}$. A specially made tool. steel cutter, shown in Figure 7 with cut specimens retained, was successfully tested on samples of core-tank screen material. The long pilot of the cutter was intended to be inserted in the aligned center holes of all six screens. The smoll wire spriags serve to retain the specimens after cutting. A 20-ft-long drive shaft and housing, incorporating a rack and pinion for feeding the cutter, completed the tool. Power was supplied by a low-speed (130-rpm) air drill.

This tool was inserted blind through the shield plug and core access flange. It was presumed that the pilot was centered in the aligned center holes as it slipped easily through three screens. Drilling of the six sereens was accomplished in $5 \mathrm{hr}$ The two operators received only $10 \mathrm{mr}$ radiation exposure each.

Subsequent examination showed that the pilot had started. $i / 2$ in. west of center and passed through a broken screen. In the drilling process the tool-steel pilot was broken off at the retainer springs. During withdrawal two of the specimens were stripped off the pllot, but the other four came out in the cutter. One of the dropped discs was subsequently retrieved. These five specimens were submitted to the metallurgical examination facility for study. The 2-in. bole through the diffuser screens allowed a specially comstructed tiltwmirror periscope w1th its own light source to be inserted for viewing between the screens. The bole was readily observed and photographed. Because of 'the restricted space no one position of the periscope gave a good view of the entire hole. Flgure 8 is a composite photograph made from pictures taken through the pexiscope.

Recovery of Corrosion Specimens Dropped on the Core Diffuser Screens

To expedite the over-all program of retrieval of the corrosion specimens from the diffuser screens, two separate groups were started on the desigrs and construction of equipment and the perfection of techniques required to operate it. This work was in progress while the core interior was beiag viewed and. the 2-in. holes were belng cut ia the diffuser screens.

One approach combined an essentially standard tllt-mirror periscope and a pair of remotely controlled fiagers to pick up the corrosion specimens. The original model is illustrated in Figure 9 in operating position over a screen mockup prepared for the purpose.

The aluminum cup inserted in the bole in the center of the screens served to receive the specimens after pickup. The cup had to be inserted and removed by a spectal tool. In operation it was first necessary to lower two projection lamps encased in screen into the core vessel suspended by their cords. The periscope manipulator was then inserted through the same 2-in. opening, and the samples were located visually. The normal pickup was made with the arm horizontal. The whole device was then raised until 
the arm could swing down to the vertical and drop its specimen into the cup. One limitation was the necessity of plcking up specimens with the arm in a near-horizontal position, limiting the field of operation to the radius of the arm. This limitation was partially overcome by grasping one sample and usiag it to push another one into a position where it could be reached.

It was apparent that many of the specimens fell through the screens during the drilling operation since only 4 of the original 22 specimens were recovered from the top screen.

The loss of specimens was explained by the discovery that the top screens had become completely detacbed from the core vessel. By standing the two top screens on edge and retrieving on the third screen, six additional specimens were recovered with the periscope manipulator.

The alternate recovery approach lavolved the use of an external-light-source viewing device and long-handled tools. The viewing device is shown in Flgure 10. Illumination is supplied by a zirconium oxide arc light with a collimating lens. system to project a beam of light down through the shield plug and into the reactor vessel. The 45-deg Stellite mirror had a 1/2-ia. hole drilled through its center to allow this light beam to pass through. The image in the mirror is viewed through a 15-power spotting telescope. When focused on the screens $20 \mathrm{ft}$ away, the long-handled manfpulator tools appear as a blur except at the working end. The field of vision is about 3 in. In diameter.

One of the 2-in. screen specimeas that had dropped during drilling was retrieved with this equipment, as well as a corro: sion specimen which could not be reached by the periscope manipulator. The screens were plumbed for elevation and tested for rigidity. By means of a dental-type mirror it was possible to look back between screens and jocate corrosion specimens. An electrically heated blob of sealing wax on a piece of Fiberglas tape was maneuvered into position and removed an additional corrosion specimen which could not otherwise be reached.

In all, 11 of the 22 corrosion specimens were retrieved. The others were wedged down between screens where they are inaccessible.

\section{Televiston Viewing Device}

The television viewing device, although thoroughly tested in the mockup and found to operate quite satisfactorily, was never inserted in the reactor since the hole was observed with simpler and less expensive equipment. However, the device (FIg. II) has many features of general interest.

The television camera, developed by Dage Company for ORNL, is only $2 \mathrm{in.} \mathrm{in} \mathrm{diameter} \mathrm{and} 8 \mathrm{l} / 2 \mathrm{ln}$. long. The preamplifier is in a larger metal case $10 \mathrm{ft}$ away from the camera. Many of 
the electronic components are thus removed from the intense radiation field, and the camera size is reduced sufficlently to allow it to be inserted in the core or blanket.

The manipulator consists of three articulated 18-10. links on a 20-ft-long mast. The liniss are moved hydraulically and the angularity of each joint is continually indicated by linear potentiometers driven by a rack and pialon. A panel containing the control valves for the hydraulic cylipders and position-indicating meters is mounted on the top of the mast.

The mast is calibrated for depth of insertion and has an azimuth ring built lato the support bushing. Since the link position indicators read only relative argular displacement, the actual position of the camera is continually followed on a small wooden model set up near the operator.

Insertion of the camera and manipulator in the blanket vesse requires numerous steps in a programmed maneuver worked out in the mockup.

\section{C̈ONCLUSION}

in

In conclusion, it might be said "that maintenance operations on a reactor such as the HRE-2 appear to be quite practical. Many highly radioactive components bave been installed and removed from the reactor, methods of controlling air-borne contamination have been developed, and relatively simple shielding, coupled with rigid health physics control, can prevent excessive exposure of personnel to radiation. The use of a maiatenance mockup proved extremely valuable in preparation for operations which were not anticipated in the design of the reactor.

\section{REFERENCES}

(1)

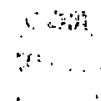

(1) S. E. Beall and.R. W. Jurgensen, "Direct Maratenance Practices for the Homogeneous Reactor Test, "ORNL-CF-58-4-101, April 18, 1958. (Presented at the Nuclear. Engineering and - Science Congress in Chicago, Illinols in March 1958). 
TABLE I. MAINTENANCE OPERATIONS PERFORMED IN HRE-2

\begin{tabular}{|c|c|c|c|c|c|c|}
\hline Type of Operation & $\begin{array}{c}\text { Date } \\
\text { of Work }\end{array}$ & $\begin{array}{r}\text { Wet } \\
\text { or } \\
\text { Dry }\end{array}$ & $\begin{array}{c}\text { Crew. } \\
\text { Hrs. } \\
\text { Reg'd } \\
\end{array}$ & $\begin{array}{l}\text { Maximum } \\
\text { Activity } \\
\text { Levels } \\
\end{array}$ & Source of Max. Radiation & $\begin{array}{l}\text { Max. } \\
\text { Pers. } \\
\text { Exp. (mr) }\end{array}$ \\
\hline Wiring installation & Feb. 25-Mar. 23 & $\mathrm{DW}$ & 152 & $<5 \mathrm{mr} / \mathrm{hr}$ & Background above shield water & $<20$ \\
\hline $\begin{array}{l}\text { Replacement of } \\
\text { corrosion specimens } \\
\text { at main circ. pump }\end{array}$ & Feb. 25-Mar. ? & $\bar{W}$ & 48 & $<5 \mathrm{mr} / \mathrm{hr}$ & Background above shield water & $<20$ \\
\hline \multirow[t]{3}{*}{$\begin{array}{l}\text { Corrosion specimen } \\
\text { removal }\end{array}$} & Apr. 8 & D & 8 & $400 \mathrm{mr} / \mathrm{hr} 60 \mathrm{ft}$ & $\begin{array}{l}\text { Blanket corrosion specimen assembly } \\
\text { and neutron source }\end{array}$ & 20 \\
\hline & July 7 & D & $131 / 2$ & $100 \mathrm{r}$ at $3 \mathrm{ft}$ & Fuel corrosion-specimen as sembly & 50 \\
\hline & Sept. 16-18 & D & 23 & $204 \mathrm{r}$ at $3 \mathrm{ft}$ & Fuel corrosion-specimen assembly & 110 \\
\hline \multirow{3}{*}{$\begin{array}{l}\text { Replacement of } \\
\text { corrosion specimens }\end{array}$} & May 4-5 & $\mathrm{D}$ & 30 & $1.5 \mathrm{r} / \mathrm{hr}$ at $\mathrm{l} \mathrm{ft}$ & Fuel access-opening beam & 120 \\
\hline & July 19-24 & D & 30 & $\begin{array}{l}2.45 \mathrm{r} / \mathrm{hr} \text { at } \\
35 \mathrm{ft}\end{array}$ & $\begin{array}{l}\text { Blanket specimen assembly and } \\
\text { neutron source }\end{array}$ & $<20$ \\
\hline & opt. 8 & $\mathrm{D}$ & 12 & $10 \mathrm{r} / \mathrm{hr}$ at $5 \mathrm{ft}$ & $\begin{array}{l}\text { Blanket specimen assembly and } \\
\text { neutron source }\end{array}$ & $<20$ \\
\hline $\begin{array}{l}\text { Blank rupture disc } \\
\text { installation }\end{array}$ & May $13-14$ & DW & 16 & $100 \mathrm{mr} / \mathrm{hr}$ & Background above shield opening & $<20$ \\
\hline $\begin{array}{l}\text { Fuel feed-pump } \\
\text { replacement }\end{array}$ & July 26 & $\bar{W}$ & 8 & $55 \mathrm{mr} / \mathrm{hr}$ & Background above shield water & $<20$ \\
\hline $\begin{array}{l}\text { Valve replacements } \\
\text { LCV }-145\end{array}$ & May 2 & $\bar{W}$ & 8 & $1.5 \mathrm{r} / \mathrm{hr}$ & Background above shield water & 220 \\
\hline HCV-141 & Oct. $13-14$ & W & 14. & $400 \mathrm{mr} / \mathrm{hr}$ & Background above shield water & 300 \\
\hline HCV -142 & Oct. $17-30$ & $\bar{W}$ & 12 & $400 \mathrm{mr} / \mathrm{hr}$ & Background above shield water & 210 \\
\hline $\begin{array}{l}\text { New line } 291 \\
\text { installation }\end{array}$ & oct. 29-30 & $\bar{W}$ & 12 & $750 \mathrm{mr} / \mathrm{hr}$ & Background above shield water & 210 \\
\hline $\begin{array}{l}\text { Insert blanket } \\
\text { gasket line } 204\end{array}$ & May 5-6 & $\overline{\mathrm{D}}$ & 3 & I r/hr at $1 \mathrm{ft}$ & Beam through shield-plug hole & $<20$ \\
\hline $\begin{array}{l}\text { Install, remove fuel } \\
\text { standpipe }\end{array}$ & $\begin{array}{l}\text { Oct. } 3 \text { and } \\
\text { Nov. } 7 \text {. }\end{array}$ & D & 12 & $4 \mathrm{r} / \mathrm{hr}$ at $1 \mathrm{ft}$ & Beam through lead-shield opening & $<20$ \\
\hline Install dip tube & Oct. $20-21$ & $\mathrm{D}$ & 16 & $3 \mathrm{r} / \mathrm{hr}$ at $1 \mathrm{ft}$ & Beam through lead-shield opening & $<20$ \\
\hline
\end{tabular}




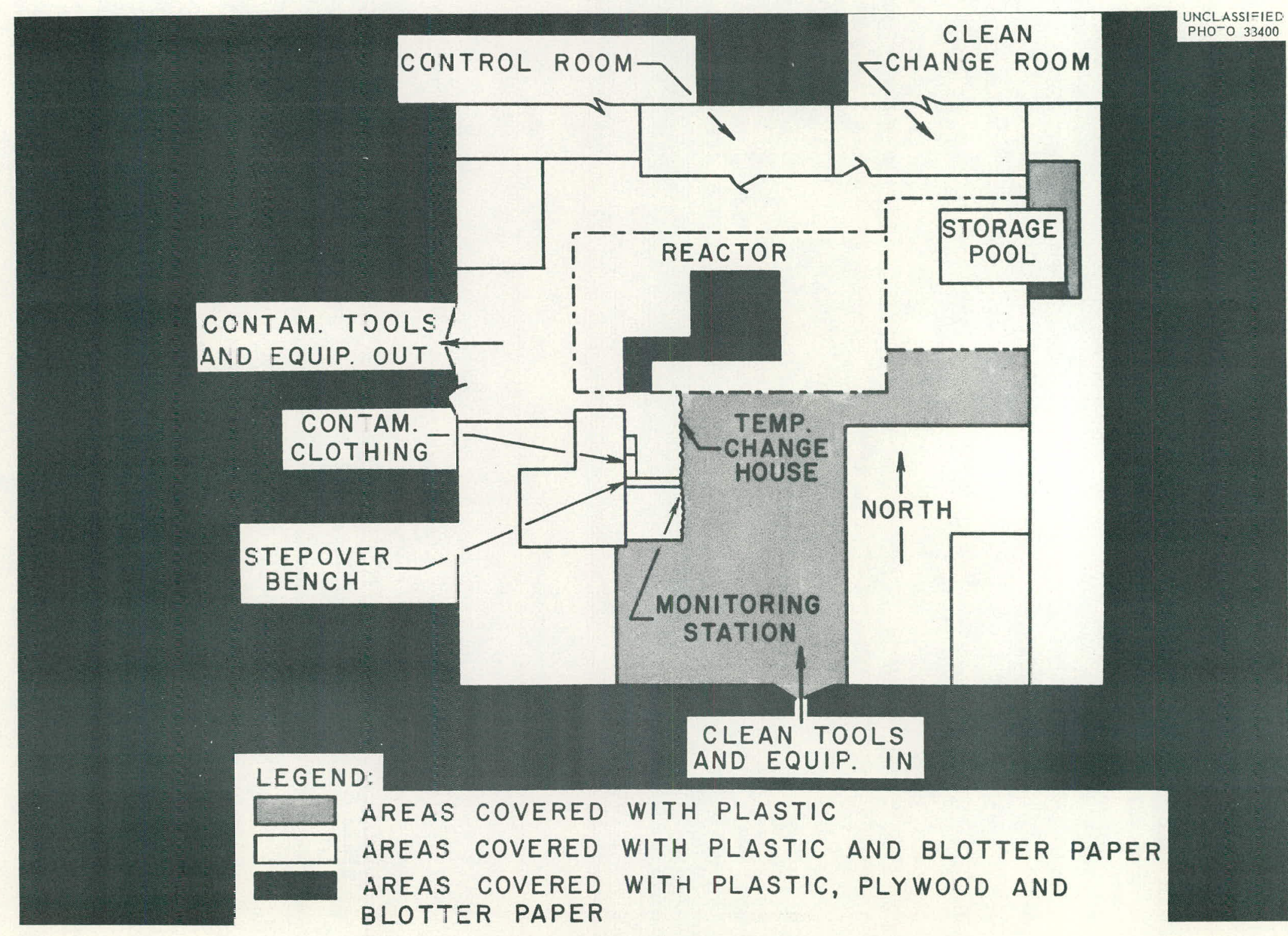

Fig. 1. Traffic Pattern in HRE-2 Building. 


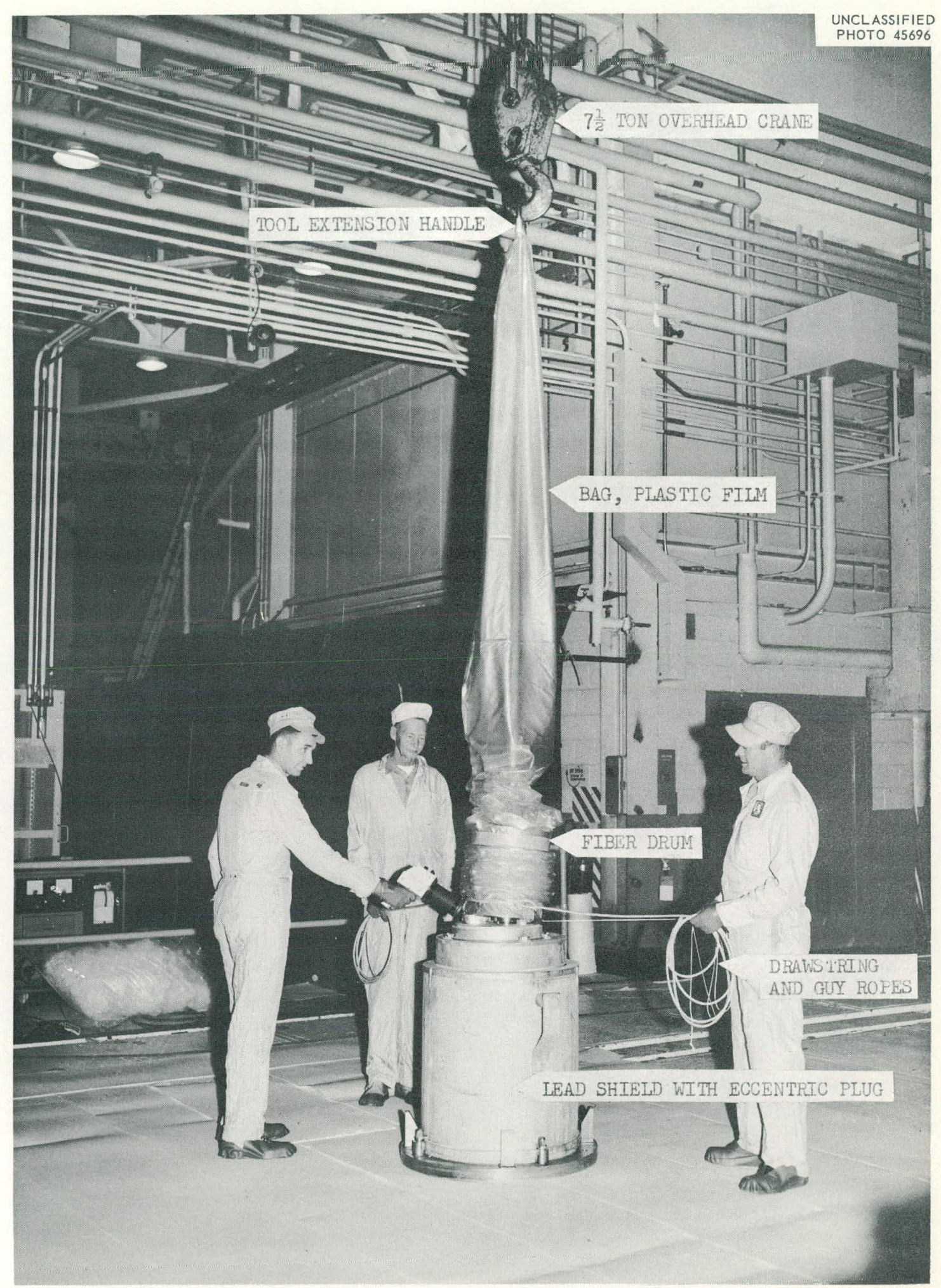

Fig. 2. Method of Containing Contamination on Tools Withdrawn from HRE-2 Core. 
UNCL ASSIFIED

PHOTO 33682

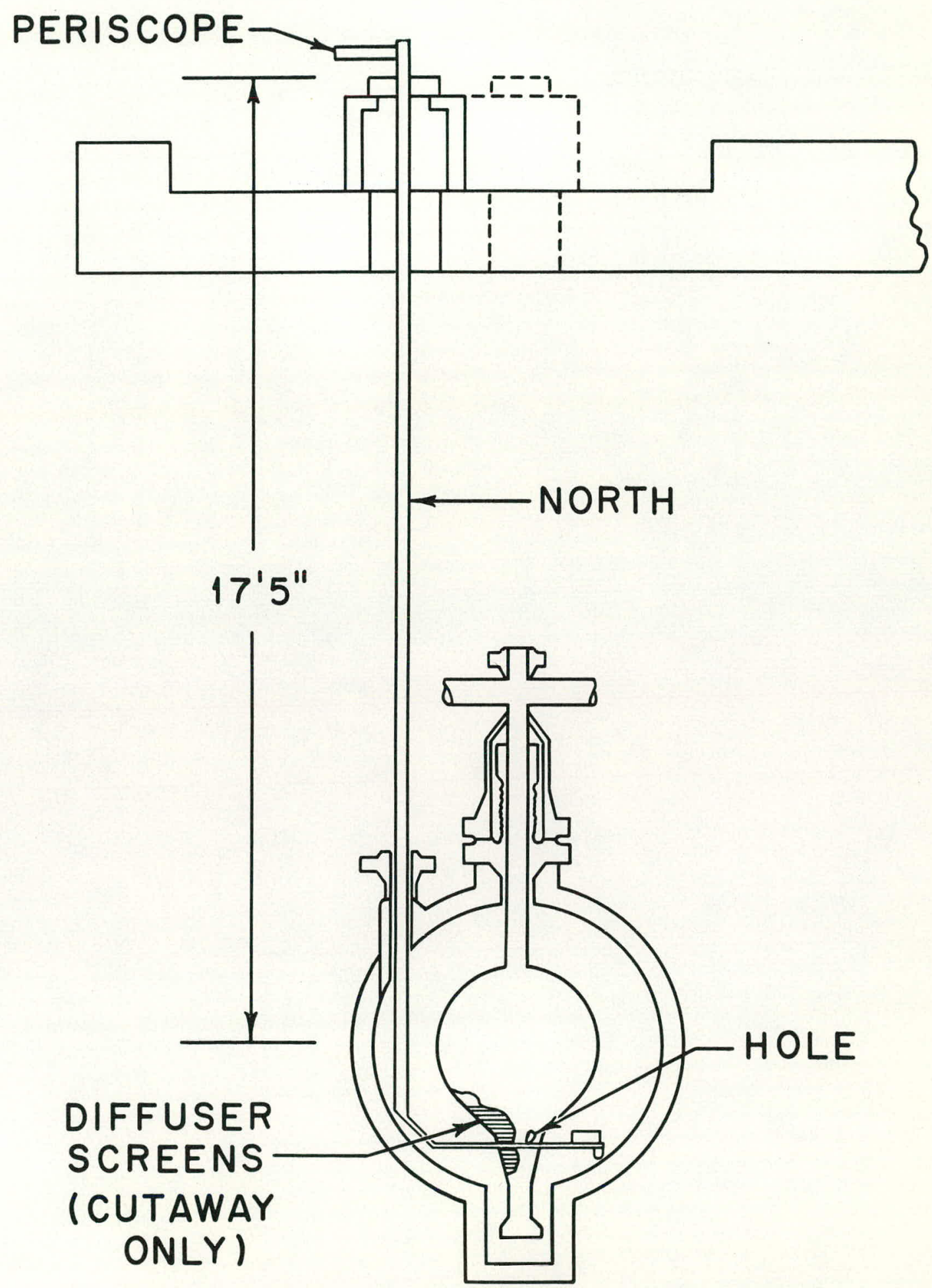

Fig. 3. Location of Cell Access Holes Relative to Core and Blanket Vessels. 


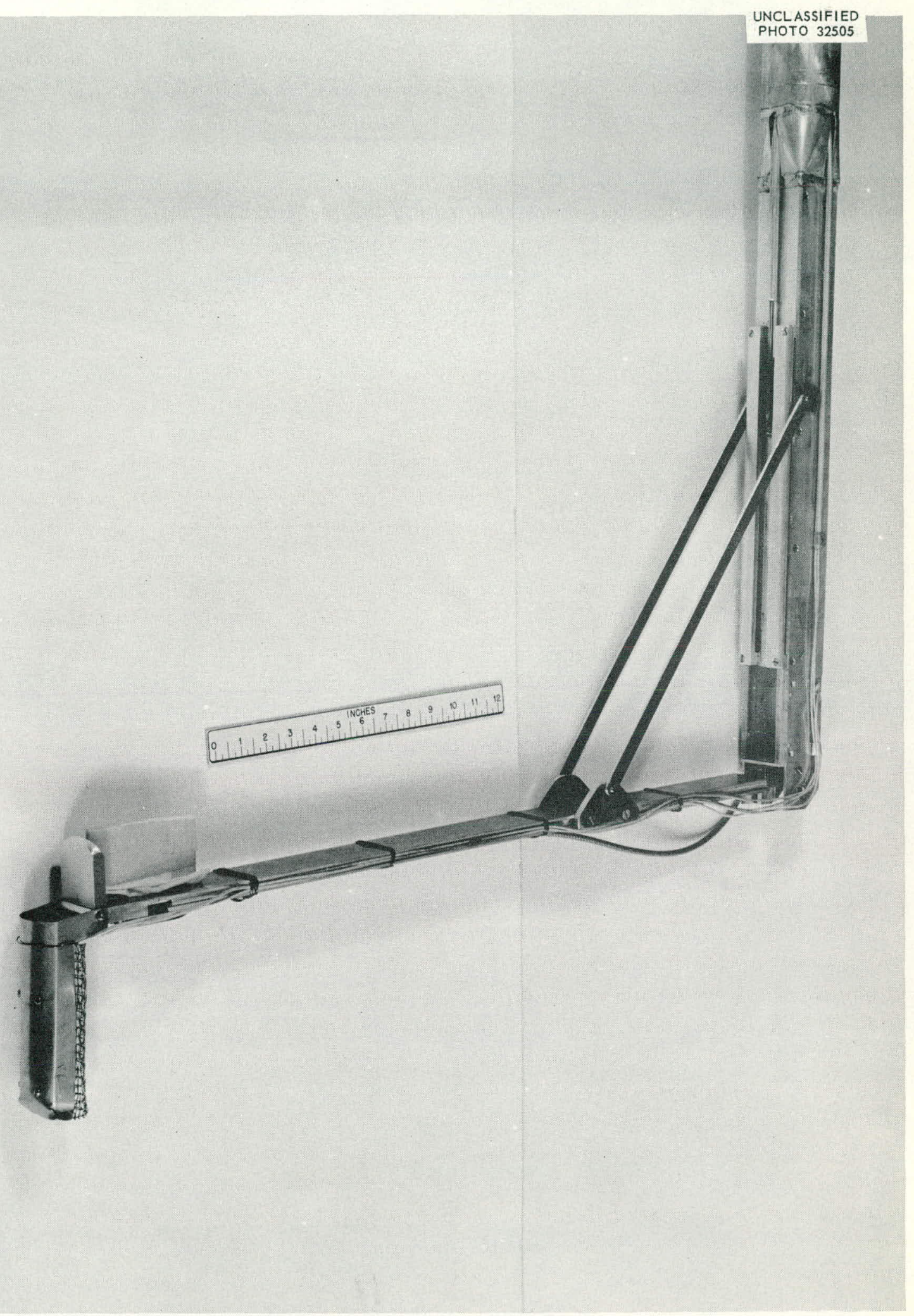

Fig. 4. Folding Arm Viewing Device. 


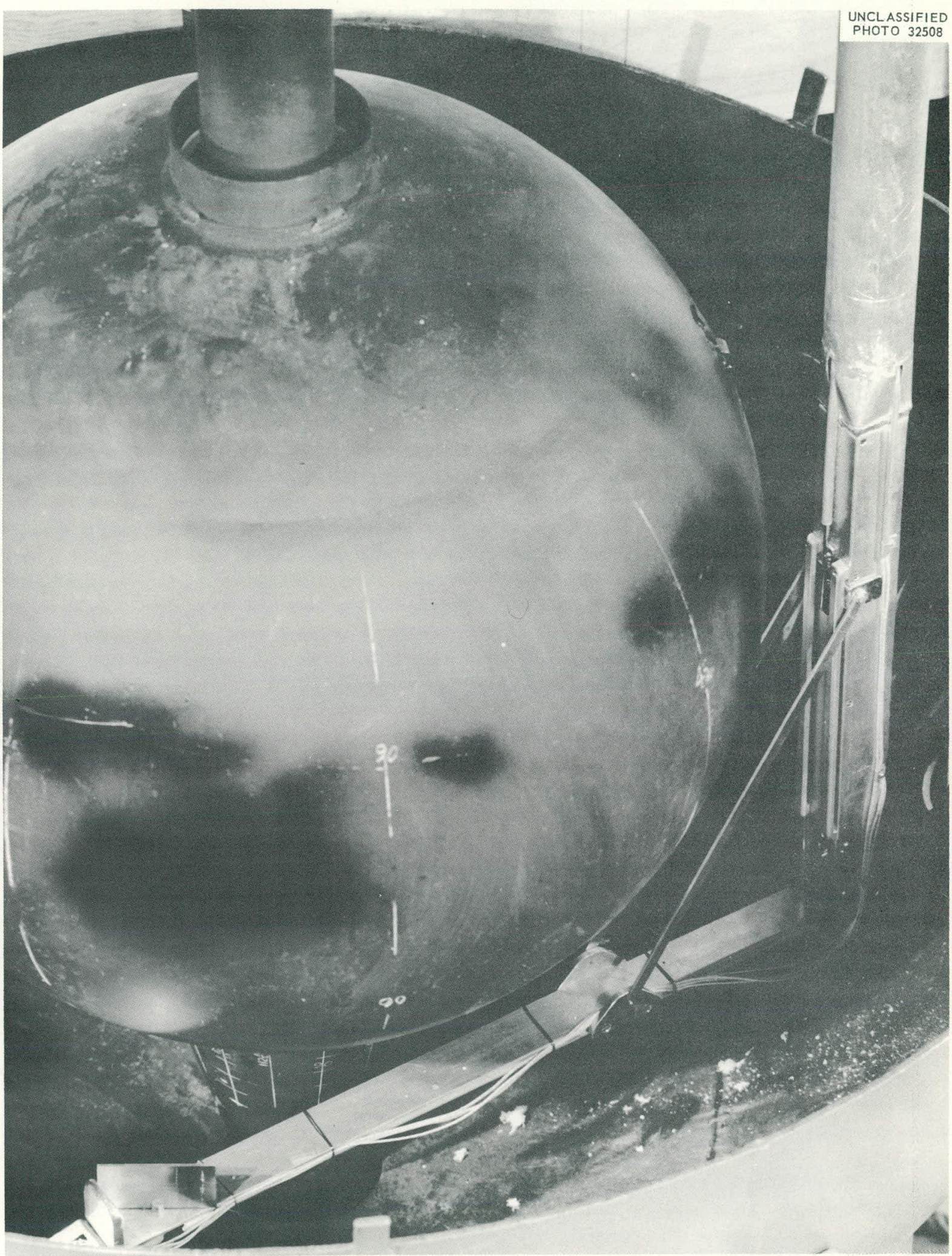

Fig. 5. Folding Arm Viewing Device Inserted in Core Mockup. 


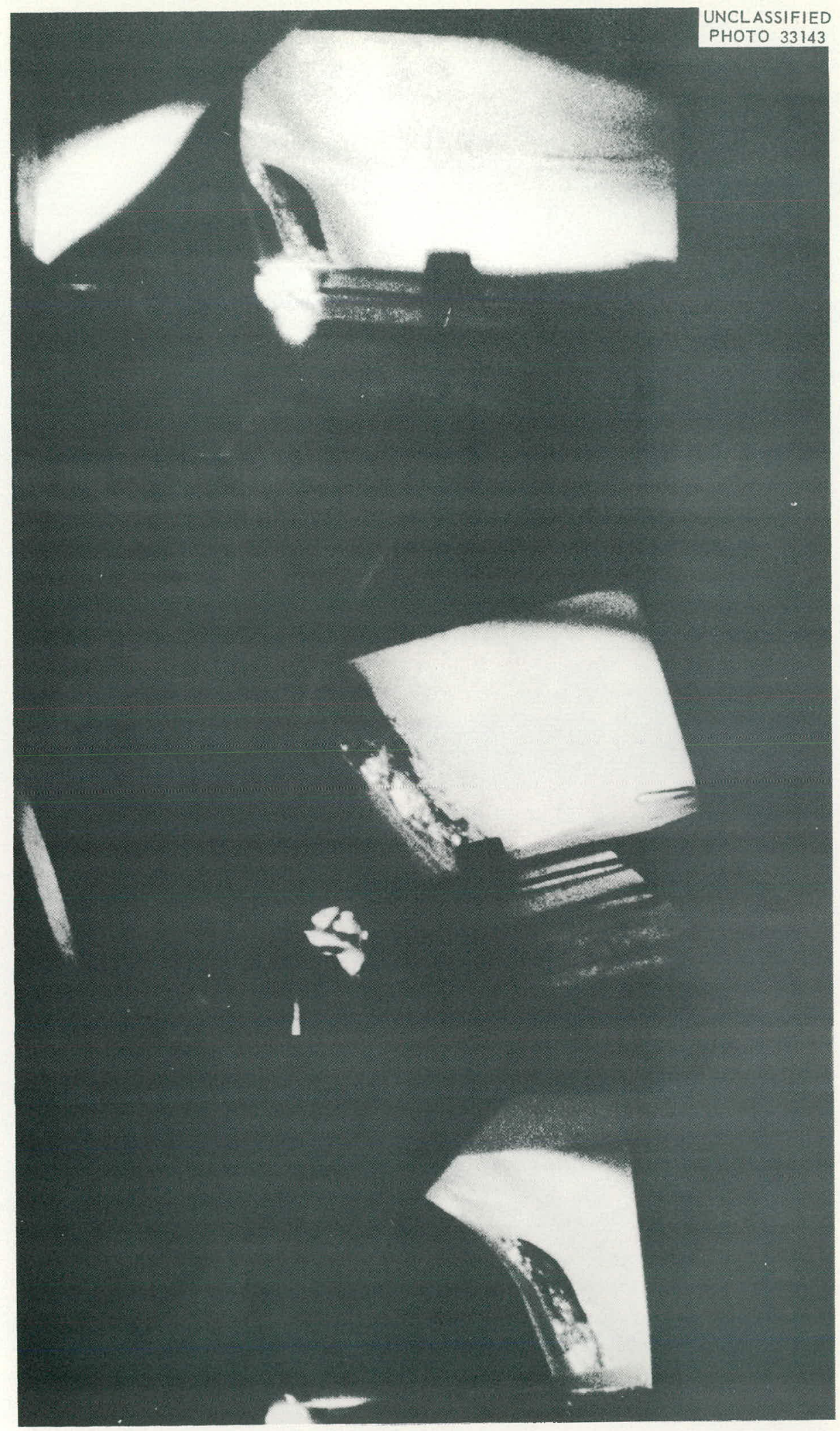

Fig. 6. Photographs of Hole in Core Made Through Folding Arm Viewing Device. 

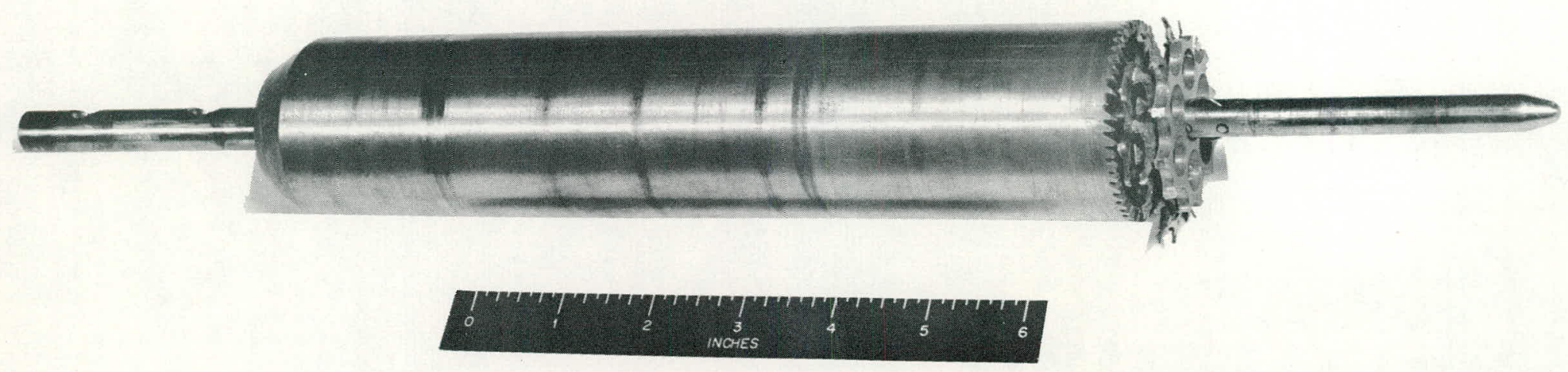

Fig. 7. Screen Sample Cutter. 


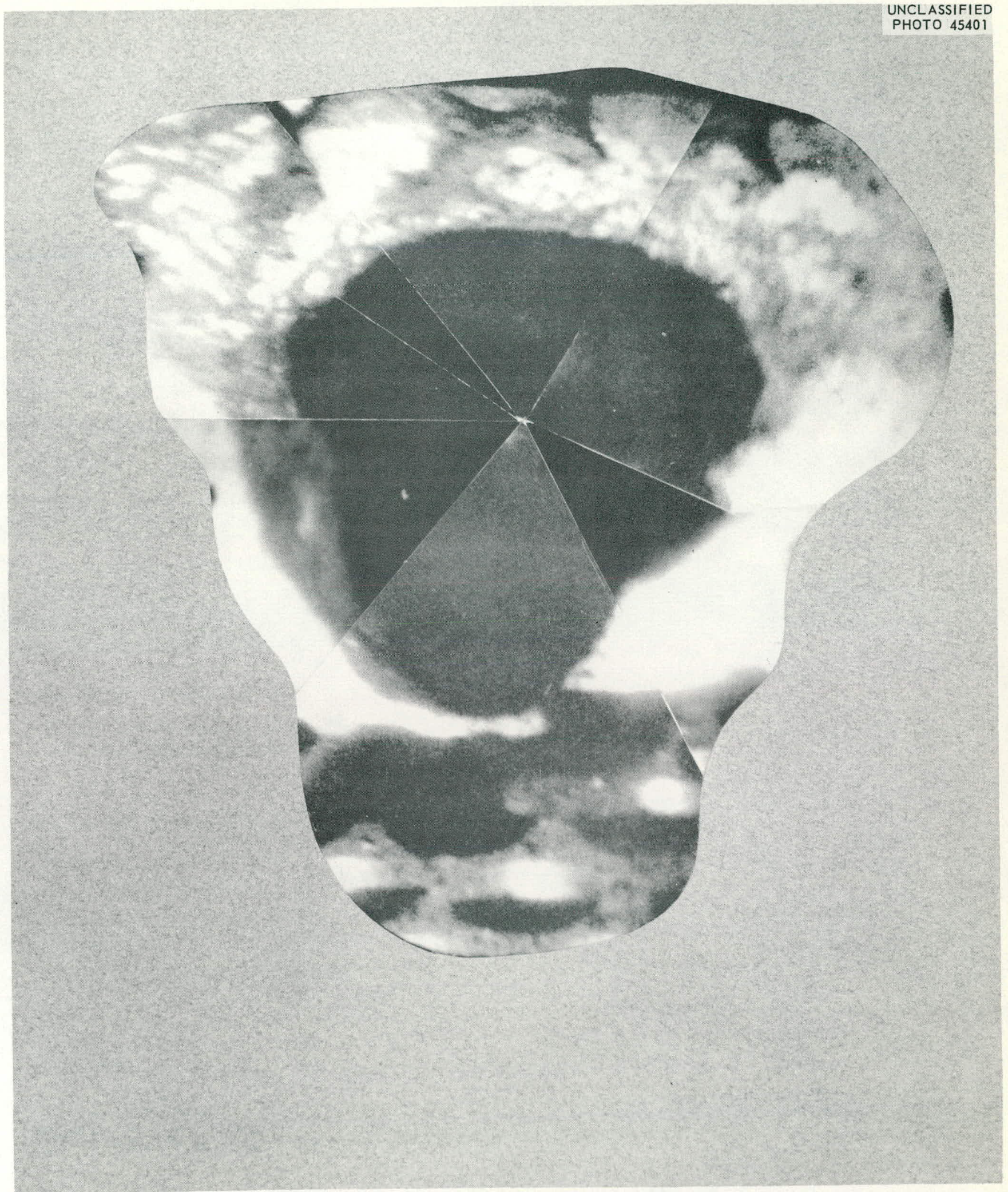

Fig. 8. Composite Photograph of the Hole in the HRE No. 2 Core Tank as Viewed from Inside. 


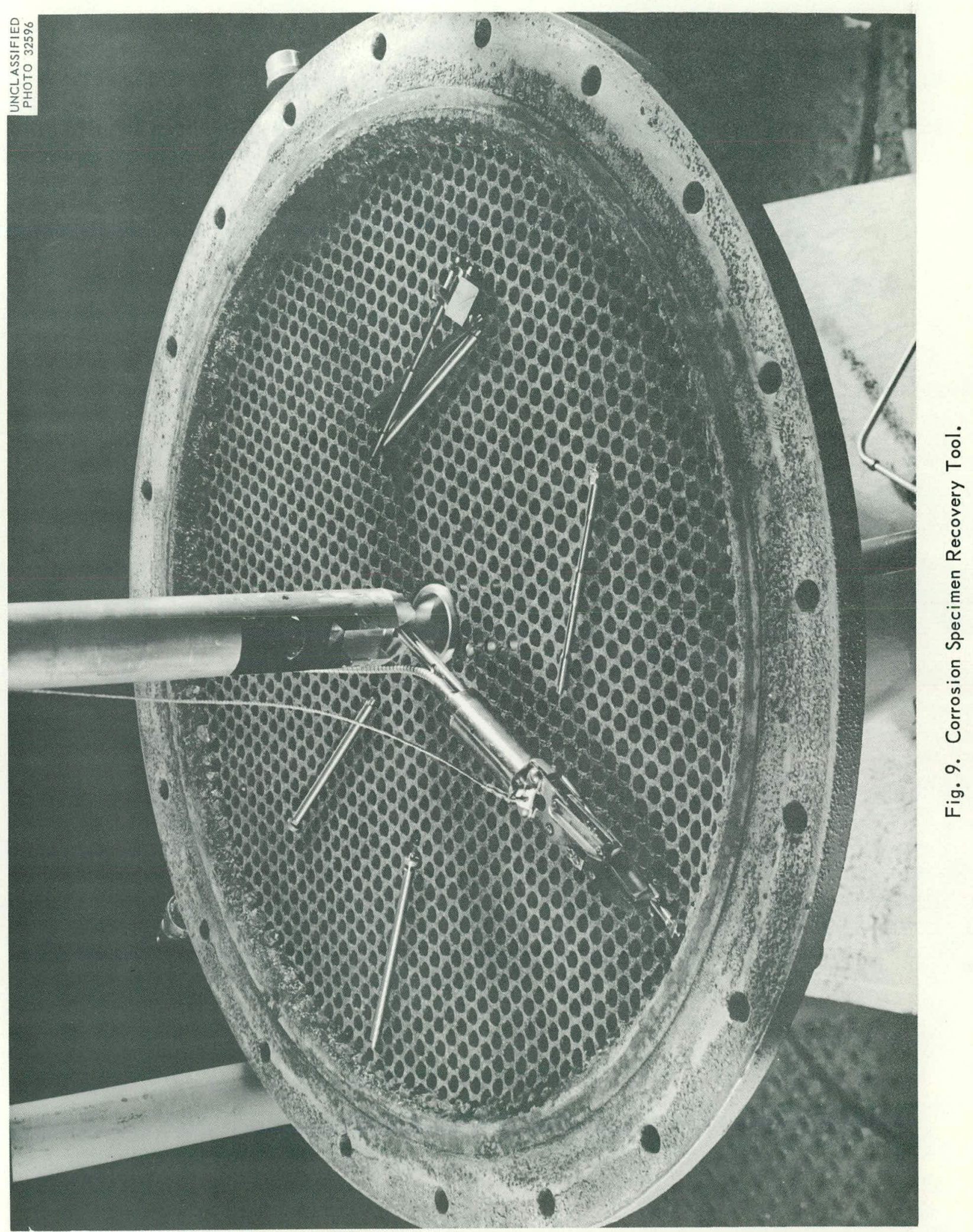




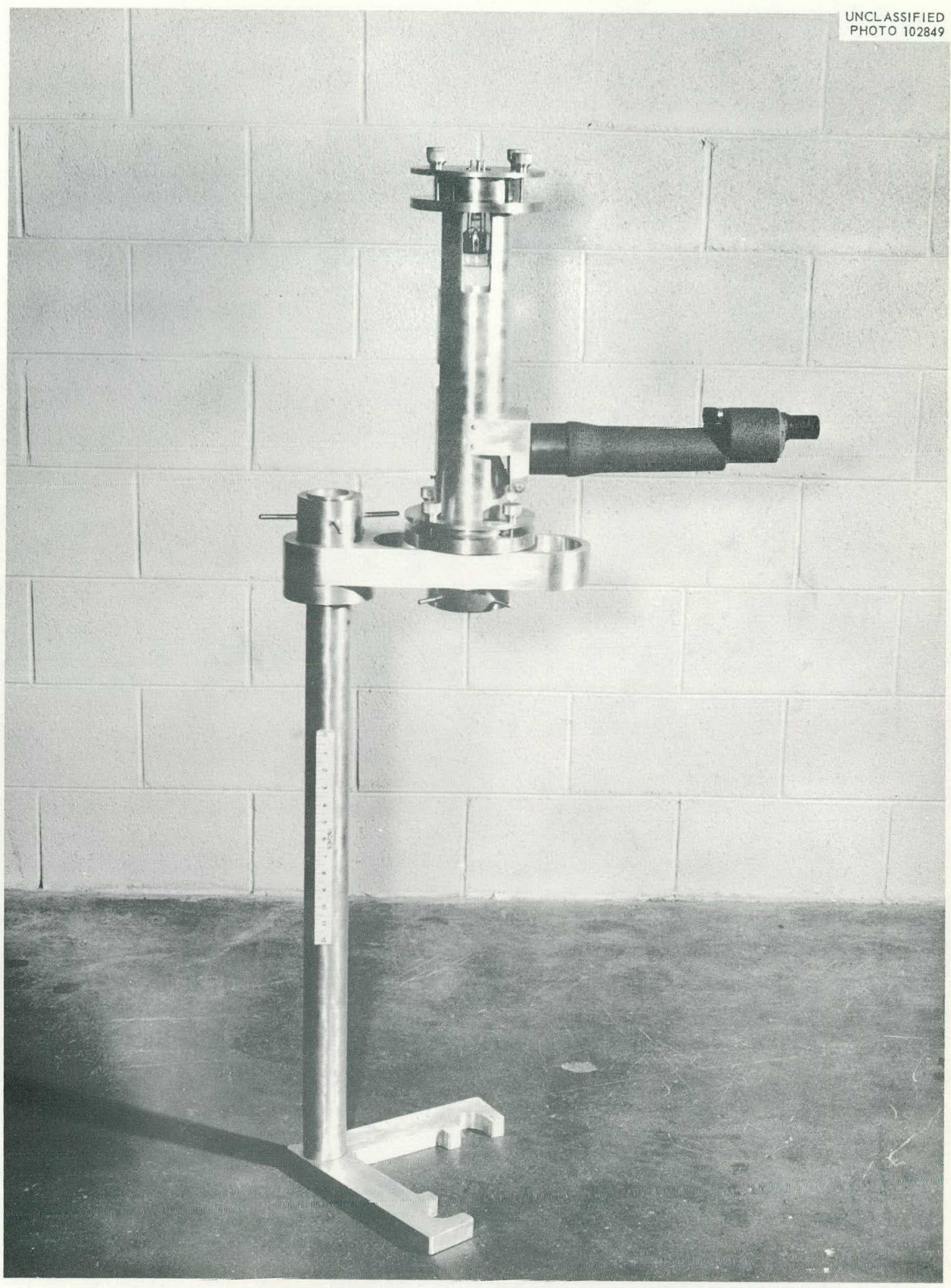

Fig. 10. External Light Source Viewing Device. 


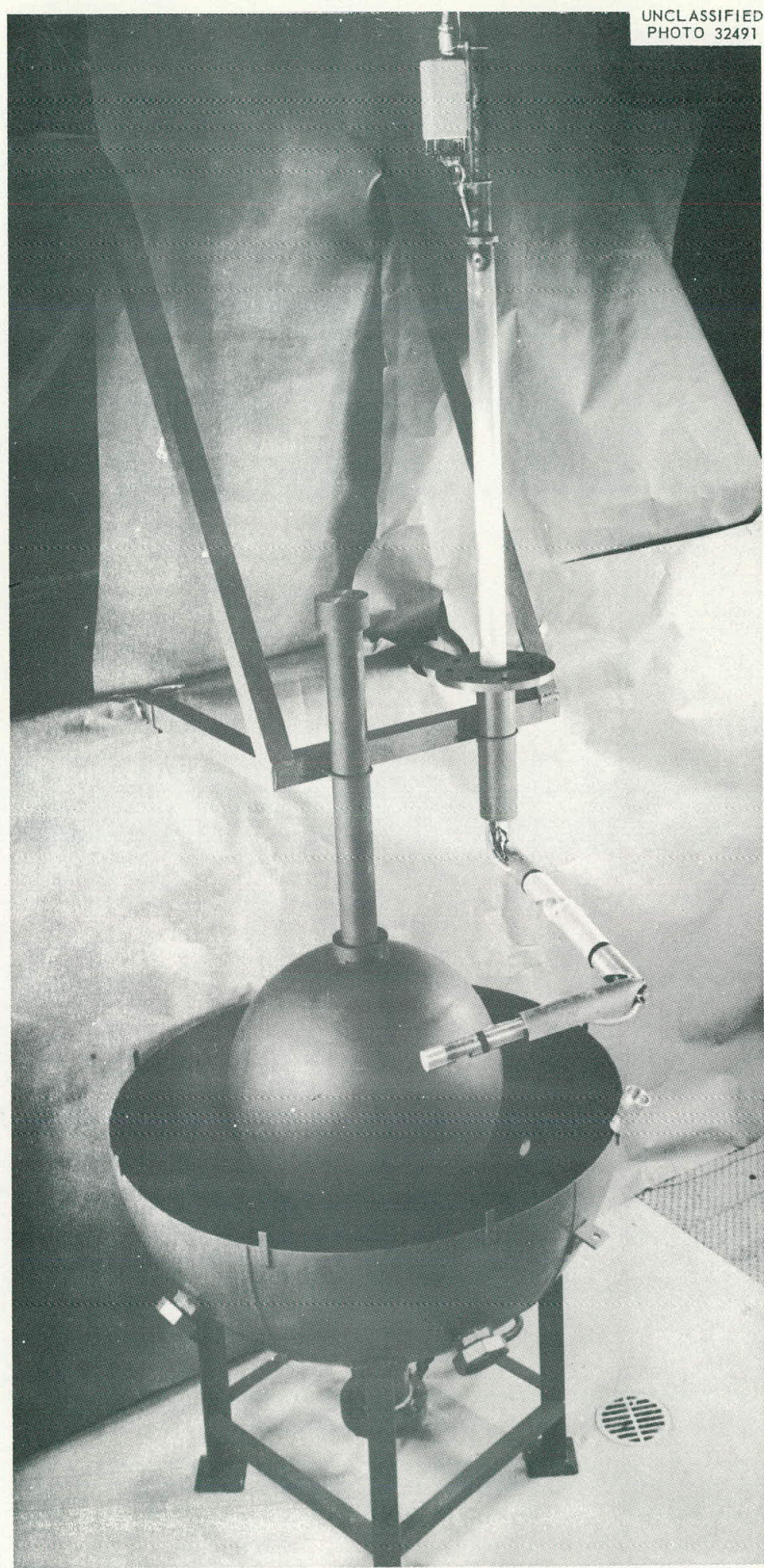

Fig. 11. Television Viewing Device Inserted in Core Mockup. 
DISTRIBUTION

1. HRP Director's Office

Rm. 259, Bldg. 9204-I

2: G. M. Adamson

3.. S. E. Beall

4: A. M. Billings

5: E. G. Bohlmann

6: S. E: Bolt

7. Jo R. Brown

8\%. W. D. Burch

9: R: H: Chapman

10: R. D. Cheverton

11: H: C. Claiborne

12: C. W Collins

13: E.

14: J. S. Culver

15: D. G. Davis

16. R: J: Davis

17: O. Є̂. Dean

18\% D. M. Eissenberg

19: J. L. English

20: D. E. Ferguson

21: C. H. Gabbard

22. W. R. Gall

23: R. So Greeley

24: J: $C:$ Griess

25: W. R: Grimes

26: P. A. Haas

27: P. Ho Harley

28. P. No Haubenreich

29. J. W: Hill

30. E。 C. Hise

31: G. H: Jenks

32. D. T. Jones

33. P. R: Kasten

34: G. W. Keilboltz

35. N. A. Krohn

36. C. G. Lawson

$37 \%$ W. H. Lewis

38. R. A. Lorenz

39.: M. I. Lundin

40. R. N. Lyon

FXTERRNAL
41: W. Lo Marshall

42: J. P. McBride

43. H. F. McDuffie

4li. H. A. McLain

45. R. A. McNees

46: JoR. McWherter

47: R. L. Moore

48. C. S. Morgan

49: L. F. Parsly, Jr.

$50 \%$ F. N. Peebles

51. M。 L. Picklesimer

52. S. A. Reed

53: D。 Mo. Richardson

54. R. C. Robertson

55. H. C. Savage

56: C. H. Secoy

57. C. L. Segaser

58. D. M. Shepherd

59: M. Do Silverman

60: M. Jo Skinner

6I: I. Splewak

62: J. A. Swartout

63. E。 H. Taylor

64: D. G. Thomas

65\% M. Toblas

66. W. E. Unger

67. R. Van Winkle

68: G. M. Watson

69: A. M. Weinberg

70 . K. W. West

$71 \%$ C. E. Winters

72: F. C. Zapp

73-74: REED Library (2)

75-76: Central Research Library (2)

77-78:. Document Reference Library (2)

79-93: Laboratory Records (15)

94. ORNL-RC

95: D. H. Groelsema, AEC, Washington 96-110. TISE-AEC (15) 